\title{
The Four Ages of Education: A Few Snapshots
}

Bahaa-eddin M. Mazid

Department of English, Faculty of Languages, Sohag University

\begin{abstract}
The word education is derived from the Latin word educare which means to bring up. Another Latin word educere, means to bring forth. Therefore, education is to bring forth as well as bring up. According to Varro "Educitobstertrix, educate, nutrix, institute, pedagogues, docet, magister" i.e. "the mid-wife brings forth, the nurse brings up, the tutor trains, and the master teaches". Accordingly education does not mean only the acquisition of knowledge but it is the development of attitudes and skills. (http://studylecturenotes.com/etymological-meaning-ofeducation/)
\end{abstract}

\section{Introduction}

Katateeb has come today to refer to a certain Arab digital educational platform, but a century ago they used to mean "écolescoraniques", or "escuelas de coran", often translated as madrasahs (lit. "schools," though they never were schools except in basic sense of being places for teaching and learning. The plural word katateeb (sing. kuttaab) refers to corners of mosques or rooms attached thereto where children were taught the Holy Quran and basic Arabic and arithmetic in an extremely traditional, memorizational fashion.

A religious foundation seems to exist in almost every culture. The three R's - "readin', ritin' and rithmetic" - were not the primary goal of early schools. "In 1642, The Massachusetts General Court passed a law that required parents and guardians to be responsible for their children's ability to read and understand the principles of religion as well as commonwealth laws." Because ignorance can lead to committing sins, education was perceived as "an avenue to salvation, not the way to a better standard of living as it is considered today."(Farris and Reiman, 2014: 33)

Time seems to have come full circle; religion is no longer an important part of the curriculum of "secular" schools in many Arab countries. The forms, tools and purposes of education, in the sense of schooling or instruction, have changed as well: ancient styli have now been replaced with digital 
pens: papyri, clay tablets and rags and leather became paper and more recently screens; reed pens and quills have been replaced with pens and markers and highlighters; feathers and brushes have been replaced with digital brushes and painting with photoshop; cave walls and stones became blackboards, later white boards, and more recently smartboards; manuscripts became books, and books were later illustrated, and more recently became e-books and podcasts; notech came to be replaced by low-tech, and later by hi-tech.

A four-age history of education may be perceived, granting that different ages or phases may not coincide in different places of the world, that one phase may not replace an earlier one altogether, that the four-phase sketch may apply vertically as well horizontally; that is, the four phases can exist at the same time in different parts of the world, or even of one country or region, and of course do exist at a chronological level in the same environment or setting. One part of the world, one part of a region, or a country, may still carry over knowledge and experience from one generation to another orally, whereas another may at the same time be doing formal schooling, while a third may be engaged in using technology in teaching and learning.
Four Ages: Sketching a History of

\section{Education}

"And He taught Adam all the names, then presented them to the angels; He said: Tell Me the names of those if you are right." (Holy Quran, 2:31).

$\left(^{1}\right)$ In the beginning was the Word, and the Word was with God, and the Word was God. ${ }^{(2)}$ The same was in the beginning with God. ${ }^{(3)}$ All things were made by him; and without him was not anything made that was made. ${ }^{(4)}$ In him was life; and the life was the light of men. ${ }^{(5)}$ And the light shineth in darkness; and the darkness comprehended it not. ... ${ }^{(9)}$ That was the true Light, which lighteth every man that cometh into the world. (Bible, KJV: John 1).

Four ages of education are outlined in Figure (1) below: oral, manu-scriptural, writtenillustrated and electronic-digital. The four ages or stages may be identified in the lifespan of a single individual, a single country or region as well as in the history of humanity at large. The first teaching known to humanity is the Word of God in the Bible and the teaching of names of all things to Adam by God in the Holy Quran. The second learning experience occurs in the story of Abel and Cain, reported in the Bible (Genesis 4: 16) and in the Quran in the Table Spread Sura. Verse 31 in the Sura tells of a raven 
that is sent be God to teach Cain, having slain his brother Abel, how to bury him. Two verbs occur in the Quranic references: one is 'allam ("informed", "taught") and the other is li-yurayhu ("in order that it - the raven might show him").

Such instances in the Holy Books are justifications for a divine theory of language origin. The semantically-loaded imperative verb Piqra? ("read") - the first word revealed to Prophet Muhammad (pbuh) - in conjunction with the Prophet's response maa?ana bi qaari? ("I am not capable of reading") record at least two stages in the history of one person's education, from orality to literacy.

The Holy Quran itself - and by analogy, the Bible - is an illustration of the four ages of education outlined below. First revealed from God to the Prophet through Gebril - or Gabriel - it continued to be transmitted by word of mouth until well after the Prophet's death. Later, it was written down based on the memories of those Muslims who had kept it by heart. Eventually it came to be printed, and now it is available in many electronic and digital formats.

The Hilaali Epic, or Sirat Bani Hilal - an Arab oral epic poem that recounts the story of the $11^{\text {th }}$ century journey of the tribe of Banu Hilal from Najd in Arabia to Tunisia and Algeria through Egypt - is another illustration of moving from orality to digitality/ digitalism, so to speak. The epic has been quite formative - an important part of many Egyptians' childhood experiences. The poem had continued to be transmitted orally by local "bards," later broadcast on the radio, which was nationalized in 1947, and was not committed to writing until relatively recently. In 2008, the epic was included in UNESCO's Representative List of the Intangible Cultural Heritage of Humanity.

More or less the same may be said about the didactic-allegorical stories of Kalila and Dimna as well as the Arabian Nights. Today, these might be heard in remote villages or in grandmas' bedtime stories, on CD's and can be heard as well as watched on TV and YouTube. They have inspired many TV programs for children. They can of course be found in print, sometimes illustrated, versions, paper as well electronic/ digital. This trajectory from living voices to dead letters, then to broadcast voices and pictures, eventually to digits, with special attention to education and references to Egypt and the West, is charted in the figure below, and the elaborations that follow. 


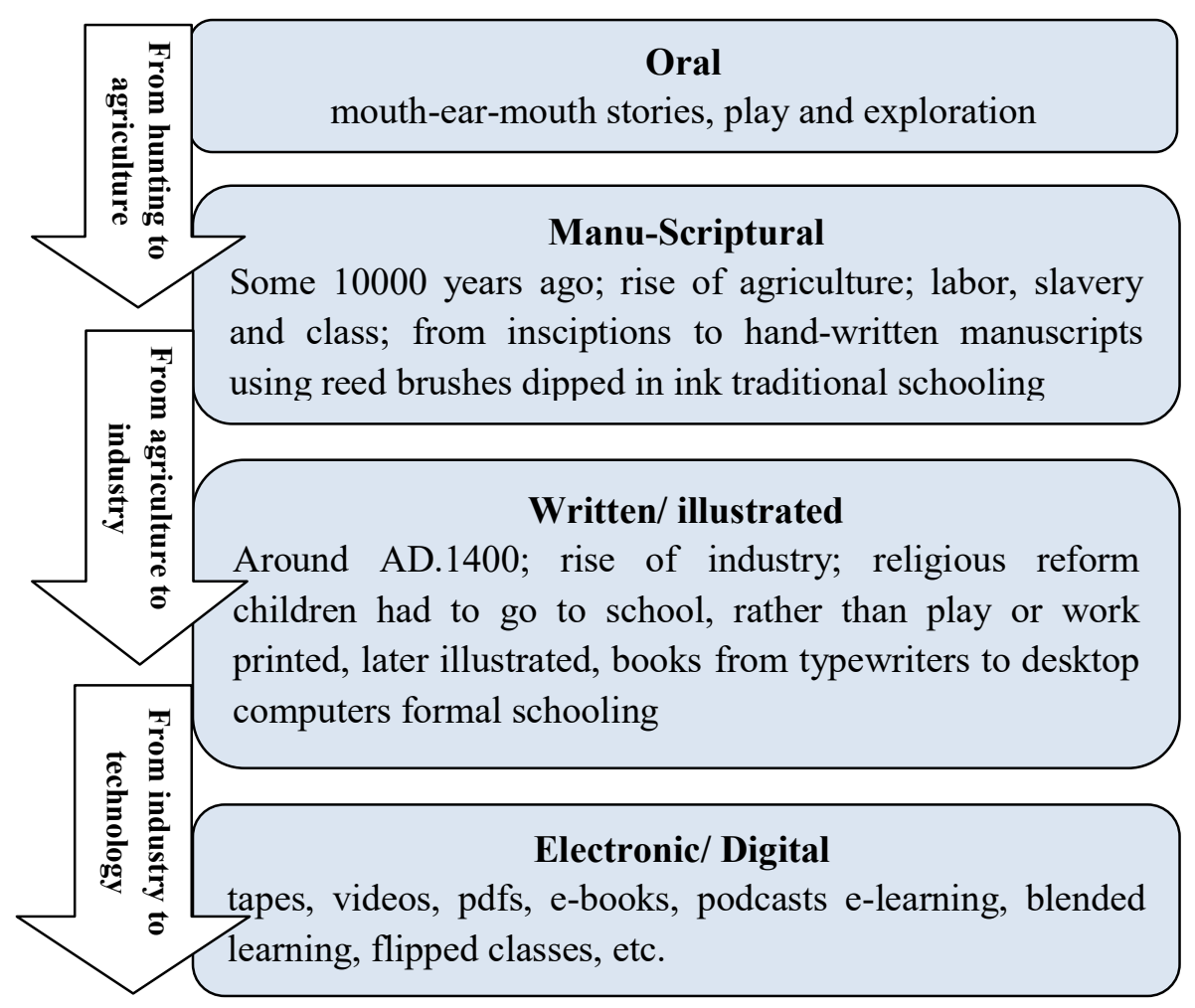

Fig (1): Four Ages of Education

\section{Oral}

"These were our bedtime stories. Tales that haunted our parents and made them laugh at the same time. We never understood them until we were fully grown and they became our sole inheritance." (Edwidge Danticat: Caroline's Wedding, 1995)

Mythological narratives, folktales and local poetry, play and exploration, rather than formal schooling of any sort, served the purposes of carrying over knowledge, experience and skill from one generation to another, most often for practical goals related to methods of survival against hunger and danger. They were definitely limited by the ability of narrators, bards and singers to move from one community to another. The scenes depicted in the following paragraph are quite typical of many oral, inevitably collectivist and most often spontaneous, traditions and cultures:

From the very first day in the life of an African child, they [sic] started hearing poetry performed, meant for their delight. It would usually be by the grandmother or some other women welcoming the new member by chanting the family oriki. During childhood, a proper and effective mode of socialization was ensured through the use of literature. So much essential information meant to ensure continuity of traditions and customs was packed into children's literature. (Isola, 2003, cited in Dasylva, 2006: 327)

Oral education has been traditionally found in places of poverty and social isolation. Yet, it is unfair to use ignorance and illiteracy interchangeably. 
Millions of adults in different parts of the world are still illiterate, and though literacy is a prerequisite for living in many modern societies, knowledge and skill can still be transmitted orally. Moreover, there is an essential oral component in every formal schooling and educators can still draw upon oral tradition in their teaching. And it might very well be damaging and impoverishing to strip humanity of its oral repertoires, though literacy remains an important and worthwhile SDG - sustainable development goal - in the modern world.

The gap between orality and literacy must have been bridged by an age of manuscripts and hand-writing. The span of time filled in with manuscripts varied from one community to another, depending on when each community became familiar with printing. And the move from orality to an age of manuscripts was in a sense a move from living performances to dead letters that have been more readily retrievable.

\section{Manu-Scriptural}

"A manuscript is essentially the earliest draft of a book. It is the unpublished version of a book submitted to agents and editors for publication considerations. (https://www.thebalancecareers.com/what-is-amanuscript-2316034)

The sense referred to in the quotation above is a fairly recent extension of the original meaning of a manuscript - a document that is hand written. Manu-scribing must have been known since time immemorial; the hieroglyphics in Ancient Egypt, 3000-1500 $\mathrm{BCE}$, pictographic, ideographic writings and cuneiforms in other parts of the world bear enough witness to this simple observation. There was schooling and training for scribes and priests in ancient Egypt, in "temple colleges," but these were elitist, only available for a privileged minority.

The long span of time between ages of hunting and ancient civilizations and the age of printing must have been filled up with manuscripts of many forms. In most "Middle Ages" in different civilizations, including the West, learning and teaching, inevitably elitist and limited in scope and reach, were done either orally or using manuscripts, or both. The transfer of Greek and Roman culture to modern Europe through translations by Arab and Muslim scholars was achieved in the same manner.

In modern Egypt, katateeb - where reed pens dipped in ink were used for writing on metal tablets or steel sheets - were the earliest forms of formal schooling. (Those writing implements, in addition to papyrus, must have been used in earlier forms of education in temples in Ancient Egypt, churches in Coptic Egypt and mosques during the Islamic period.) Al-Azhar Mosque was established between 970 and 972 to provide a more advanced religious education in a more formal manner and it must have relied very heavily on 
manuscripts. What is now Cairo University was established in 1908.

Most of those educational initiations must have relied on manuscripts, rote learning and memorization till Egypt knew printing with the French campaign on Egypt and Syria (17981801), when printing had been known well

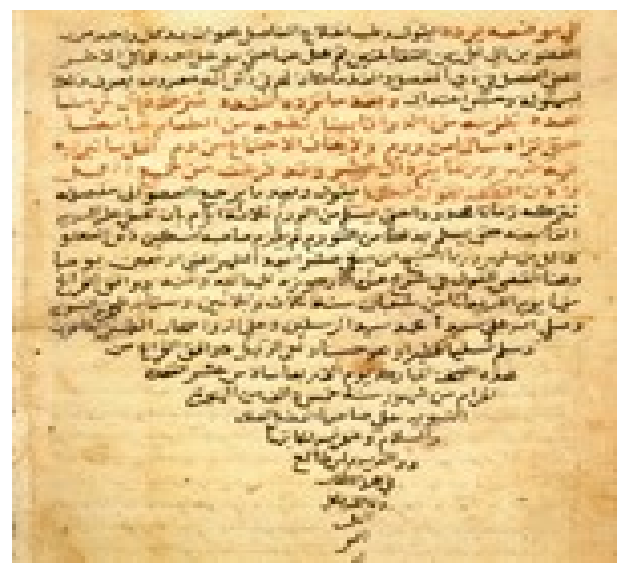

From a copy of Ibn Rushd's $12^{\text {th }}$ century commentary on the Poem on Medicine written by IbnSīnā. The copy was completed on the AH 1005, AD1597from a copy finished in AH633 AD1236.

https://www.nlm.nih.gov/hmd/arabic/poetry_3.html before in Europe. This is another reminder that education has not developed in the same way or in parallel lines, simultaneously, everywhere in the world. It is also a reminder of the changing roles of various corners of the globe in the long story of human civilization.

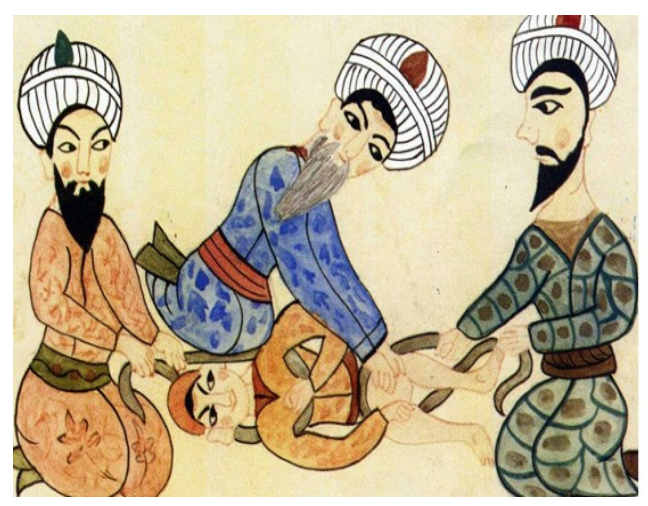

Medical treatment during the Ottoman Empire https://muslimheritage.com/attitudes-humanexperimentation-ottoman-medic/

Medicine was practiced manually, taught orally and recorded in manuscripts.

\section{Written, later Illustrated}

"Education is the kindling of a flame, rather than the filling of a vessel" (Socrates)

"He who opens a school door closes a prison" (Victor Hugo)

There of course had been "schools" before the invention of printing, but the availability of books had been quite limited. The two quotes below refer to some forms of schooling in ancient Egypt and in Athens, respectively:

From the pictures and images, it seems that classrooms had tables for the children to use to write on and lessons were taught by teachers. Some schools were designed for specific talents, such as 'Scribes'. These were the people that would have the job of writing all of the history, letters and all communications. Scribe students would spend hours writing and re-writing the hundreds of symbols that made up the Egyptian words. There is evidence that the kids didn't always like doing the work and when they skipped school, they were punished.

(https://www.historyforkids.net/egyptianschool.html)

Schools had begun to appear in those early centuries, probably on eastern Mediterranean models run by private teachers. The earliest references are, however, more recent. Herodotusmentions schools dating from 
496 bce and Pausanias from 491 bce. The term used is didaskaleion "a place for instruction", while the generic term schole, meaning leisure-a reference to schooling being the preserve of the wealthier sector-was also coming into use. There was no single institution; rather, each activity was carried out in a separate place. The young boy of privileged rank would be taken by a kind of chaperone, the paidagogos, who was generally a respected slave within the parents' household. The elements of literacy were taught by the writing master, known as a grammatistes, the child learning his letters and numbers by scratching them on a waxcoated wooden tablet with a stylus. (https://www.britannica.com/topic/education/

\section{Athens).}

With the rise of industry and religious reform movements in the West around 1400, and the shift toward individualism, decentralization and objectivism, schools in the modern sense of the word flourished and children had to go to school, rather than play or work. Early schools there, as often the case elsewhere, were predominantly religious and disciplinary.

Education in England remained closely linked to religious institutions until the nineteenth century, although charity schools and "free grammar schools", which were open to children of any religious beliefs, became more common in the early modern period. Nineteenth century reforms expanded education provision and introduced widespread state-funded schools. By the $1880 \mathrm{~s}$ education was compulsory for children aged 5 to 10 , with the school leaving age progressively raised since then, most recently to 18 in 2015.

\section{(https://en.wikipedia.org/wiki/History of edu} cation in_England)

A common attitude of eighteenth-century school authorities toward play is reflected in John Wesley's rules for Wesleyan schools: "As we have no play days, so neither do we allow any time for play on any day; for he that plays as a child will play as a man" (cited in Mullhern, 1959: 383). In the same vein, one "master" in Germany proudly kept records of the punishments he inflicted on his students in 51 years of teaching. A partial list thereof included: "911,527 blows with a rod, 124,010 blows with a cane, 20,989 taps with a ruler, 136,715 blows with the hand, 10,235 blows to the mouth, 7,905 boxes on the ear, and $1,118,800$ blows on the head" (cited in Mullhern, 1959: 383).

With schools came standardized assessment and evaluation, drills and practices, grades and stages and levels and the landscape of play and exploration seems to have been limited. And with printing, schools could make use of print books, first monomodal and later illustrated; first black and white and later colored and colorful. However, schools in Egypt had to wait for so long to adopt rather more communicative, more 
learner-oriented, more humanistic methods and strategies. (At least ostensibly, private schools have always been avant-garde in this respect).

\begin{abstract}
Al-Ayyaam (1929) - The (Stream of) Days - by Taha Hussein (1889-1973) is in a sense a partial history of the development of modern education in Egypt. Coming from a large family of very modest means living amidst tales of ghosts and jinnis, and blinded in early childhood by the clumsy practices of a local barber, in the absence of any medical schooling in his village in Upper Egypt, he was destined to a limited religious education of a traditional type in a kuttaab, and for a life in darkness. He later moved to the Azhar Mosque and Cairo University, eventually reaching the University of Montpellier in France and returning to Cairo to be the Dean of Arabic Literature. He lived long enough to move from an oral culture, to a religious school, then to two universities; long enough to be on the radio and on TV and to use a map in relief in teaching Greek civilization at Cairo University. However, he did not live long enough to see computers used for educational purposes.
\end{abstract}

Public schools have always been busy inculcating ideas, values and attitudes in a predominantly theoretical manner. A lot of teaching, with a lot of repetition and lecturing, with little play, little creativity or critical thinking, little problem-solving, and so many do's and don'ts is a form of inculcation. Summing up a very rationalist, positivist philosophy, Mr. Gradgrind, in the opening lines of Charles Dickens' Hard Times (1854), thus commands a teacher: "Now, what I want is Facts. Teach these boys and girls nothing but Facts. Facts alone are wanted in life. Plant nothing else, and root out everything else. You can only form the minds of reasoning animals upon Facts; nothing else will ever be of any service to them"

\section{Electronic-Digital}

"Digital reading will completely take over. It's lightweight and it's fantastic for sharing. Over time it will take over" (Bill Gates)

"If you are on social media, and you are not learning, not laughing, not being inspired or not networking, then you are using it wrong" (Germany Kent).

Manuscripts and schools seem to have narrowed the landscape and scope of education in its general sense, either because of the limitations of hand writing and distribution, or because of the limitations of a cemented building. Educational technology came to solve many of those issues and has proven to be very fruitful in many communities. From a focus on content to a focus on mode and 
format to a focus on interaction between learners and technologies to a focus on learning environments (Winn, 2002), educational technologies seem to have become an integral part of many educational institutions today.

The shift from no-tech to low-tech and then to hi-tech, and the advance from computers to microcomputers to the Internet and later to mobile technologies have not been occurring in the same manner in the same speed and efficiency in every community.
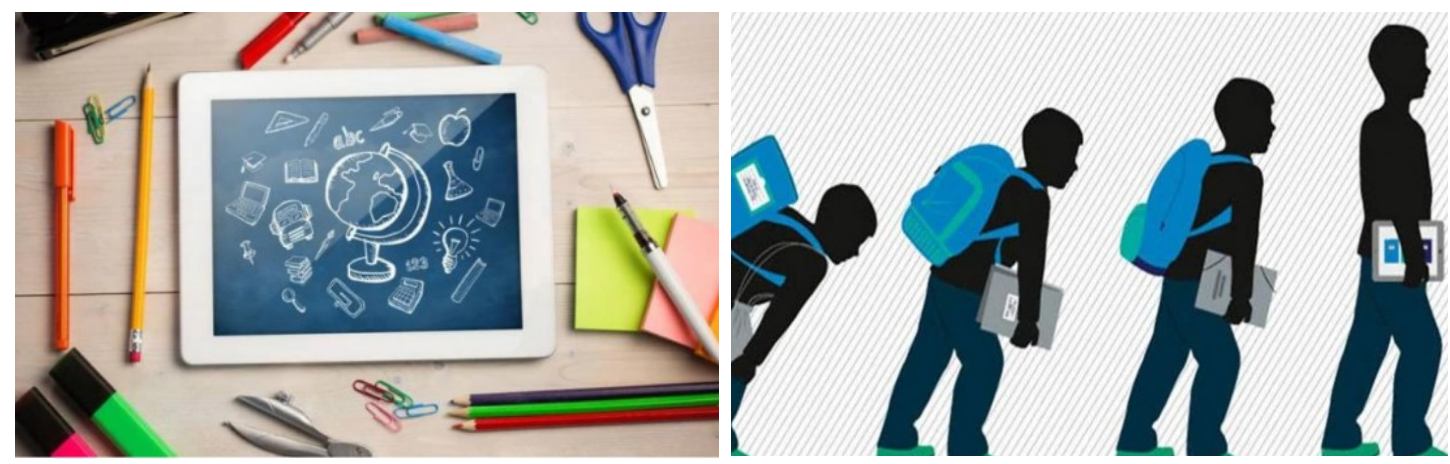

https://www.indiatoday.in/education-today/featurephilia/story/digital-education-education-system-in-indiadivd-1594399-2019-09-02

There is so much to say about the opportunities availed and the threats posed by educational technologies. The two graphic texts above sum up a lot of benefits of educational technologies and digital education. The space occupied by and the effort exerted in carrying so many books and stationery are no longer a problem, and computers have come to perform so many tasks otherwise performed by a variety of tools and implements. In addition, educational technologies are capable of freeing teachers and learners from the restrictions of
In the case of Egypt, some schools are still functioning with print books, chalk and talk; others are lucky enough to have tape recorders and cassette tapes; others are already equipped with data-shows and desktop computers. Only in privileged schools can smart-boards and similar technologies be expected. In fact, many veteran educators in many Arab countries including Egypt still question the very value of all educational technologies and still ascribe to a teacher-centered, lecturebased form of education. 
challenges. Today, education is available in all forms and formats, suitable for a variety of intelligences and of socio-economic and cultural conditions. Students can listen to a folktale on a radio, watch it on $\mathrm{TV}$, read it in a print book, or read it in an e-book or a pdf, watch it in a movie or cartoon, or on YouTube. They can chat and write about it and can produce their own videos and podcasts. A medical student can learn medicine by watching a medical expert in a real life setting, can study medicine offline or online and can attend medical webinars and watch surgical operations online.

Not every student, or teacher, has access to the Internet and may not own or have access to mobile devices. The digital-tech "divides" still persist and there are pockets of people around the globe who have no access to electricity. Safety and security is another serious challenge in dealing with digital platforms and devices. Certainly, there are laws that govern digital behavior and being online; yet, not every student or teacher is aware of them and most often they are not effective. Thus copyrights are violated right and left; bullying, fraud and phishing are part and parcel of today's digital culture.

Students today are in dire need for a digital literacy that goes beyond their ability to browse, chat and text. They need to know what laws govern their behavior online as well as in a learning lab, how they can protect themselves online, their rights as well as their obligations, what kind of manners is expected from them when they surf the net, use digital platforms or live on an SNS, the rules governing online interactions and transactions, and the opportunities they have for learning and sharing in the digital world. Education, no matter what forms or formats it takes, what designs and media it uses, should continue to develop knowledge, skill and attitude.

\section{Concluding Remarks -}

\section{"The baby in the basket"}

The journey from orality to digital education outlined above is a very, very long story cut very, very short, reduced to a few snapshots, no more. At the end of the day, all forms, modes, media and formats of education have come to live together, which provides varied opportunities that suit varied socio-economic conditions as well as teaching and learning styles.

The shift to digitalism seems to be both desirable and inevitable, though it may not be affordable everywhere. When it is affordable, it is wise not to "throw the baby out with the bath-water" - an expression which means that an entire idea, concept, practice or project does not need to be rejected or discontinued if part of it is good. (https://www.wisegeek.com/whatdoes-throwing-the-baby-out-with-the-bathwater-mean.htm).

There is a lot of wisdom and authenticity in folktales and folk poetry and there are treasures of knowledge and experience in manuscripts. Luckily, all of these discourses can be 
reproduced, adapted and made good use of with electronic and digital technologies. There are also cultural, emotional and moral appeals in using very advanced educational technologies to impart a piece of knowledge, a skill, or an attitude, while drawing upon local culture.

\section{References}

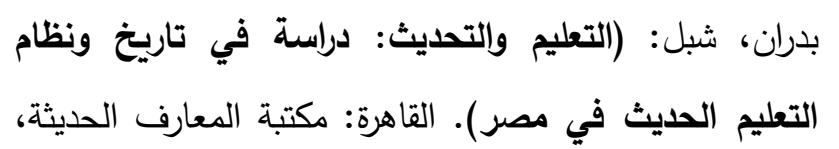

$.19 \wedge \varepsilon$

عمّار، حامد: (في التوظيف الاجتماعي للتعليم). القاهرة:

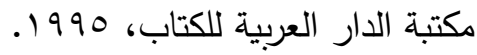

Dasylva, Ademola O. (2006). "Culture Education" and the challenge of globalization in modern Nigeria. Oral Tradition, 21(2): 325-341.

Farris, Pamela J. \& Reiman, Patricia L. (2014). Teaching, Bearing the Torch: AN Introduction to Education Foundations. Long Grove, IL: Waveland Press.

Gray, p. (2008). A brief history of education. Psychology today.

https://www.psychologytoday.com/us/blog/freedom -learn/200808/brief-history-education

Gutek, G. L. (1991), An Historical Introduction to American Education, $2^{\text {nd }}$ ed. Prospect Heights, IL: Waveland Press.

Isola, Akinwumi (2003). "Limits of Tolerance: the Future of African Cultures." Nigerian National Merit Award Winner's Lecture, Calabar, Nigeria. Ibadan: Colla.

Leicester, M., Modgil, C. \&Modgil, S. (2000). Moral Education and Pluralism. London and New York: Falmer Press,

Mulhern, J. (1959), A History of Education: A Social Interpretation, $2^{\text {nd }}$ ed. New York: Ronald Press.

Thompson, LaNette W. (n.d). Teaching nonliterate adults in oral cultures. Accessed Dec. 11, 2019. Available:

https://files.eric.ed.gov/fulltext/ED570509.pdf

UNESCO (2013). Second global report on adult learning and education: Rethinking literacy. Available:

http://unesdoc.unesco.org/images/0022/002224/222 407E.pdf

UNESCO (2014). Education for all 2013/2014 Report. Available

http://www.unesco.org/new/en/education/themes/ leading-the-

\section{internationalagenda/efareport/reports/2013/}

Winn, W. (2002). Current trends in educational technology research: The study of learning environments. Educational Psychology Review 14(3): 331-351. 